\title{
Copepod carcasses in the ocean. II. Near coral reefs
}

\author{
Amatzia Genin ${ }^{1}$, Gideon Gal ${ }^{1}$, Loren Haury ${ }^{2}$ \\ 1 The Hebrew University, H. Steinitz Marine Biology Laboratory, PO Box 469, Eilat 88103 , Israel \\ ${ }^{2}$ Marine Life Research Group, Scripps Institution of Oceanography, La Jolla, California 92093-0218, USA
}

\begin{abstract}
Copepod carcasses containing little or no internal tissue, but bearing undamaged setae and appendages, dominated zooplankton samples collected near the coral reef of Eilat, Israel. The proportions of carcasses to total copepods (living plus dead) increased from open offshore waters ( $22 \%$ ) to the reef $(65 \%)$. Proportions across a sandy shore without a reef were low $(<25 \%)$, with no significant changes with respect to distance from shore. Calanoid copepods exhibited higher proportions of carcasses than cyclopoids. Carcasses similar to those found in our plankton samples were egested in aquaria by freshly collected post-settling fish larvae and crinoids. High proportions $(>80 \%)$ of carcasses co-occurred with extremely low $\left(<100 \mathrm{~m}^{-3}\right)$ abundances of zooplankton, further corroborating a relationship between predation and carcass abundance. Since the nutritional value of carcasses is substantially less than that of living individuals, differentiating between live copepods and carcasses should be critical for planktivores inhabiting reefs, as well as for investigations of trophic dynamics in such habitats.
\end{abstract}

KEY WORDS: Copepod Carcass - Coral reef Predation

\section{INTRODUCTION}

High abundances of empty or partially empty exoskeletons of copepods have been found near the bottom of the deep sea (Wishner 1980), in deep oceanic waters (Farran 1926, Wheeler 1967, Sameoto 1986 , Terazaki \& Wada 1988), in upwelling fronts (Weikert 1977), outside dense zooplankton patches (Wishner et al. 1988) and over shallow topographic features (Haury et al. 1995, this volume). These carcasses are more transparent than copepods collected alive, due to partial or total lack of internal tissues, and commonly exhibit small exoskeletal fractures (Harding 1973, Weikert 1977, Ohman 1984, Beyer 1992).

Knowledge of the processes that produce carcasses and determine their distribution is limited (Weikert 1977). The decomposition of dead copepods can produce empty or partly empty exoskeletons (Wheeler 1967. Harding 1973). An observed increase in carcass abundance with depth has therefore been attributed to the decomposition of sinking dead copepods (Roe 1988, Terazaki \& Wada 1988). Rapid degradation of soft tissue, combined with slow digestion of chitin, particularly at low temperatures (Harding 1973), will augment the abundance of empty carcasses at depth. Predation can produce empty or partially empty copepod exoskeletons independent of decomposition. Some planktivorous micronekton (e.g. euphausiids) eat the internal tissues of their prey and release or egest partly empty exoskeletons (Ponomareva 1954, Ohman 1984, Beyer 1992). Partly digested crustacean prey were also reported for cnidarians (Sebens \& Koehl 1984, Lewis 1992), fish larvae (Rosenthal \& Hempel 1970, Chitty 1981, Checkley 1982, Conway et al. 1993), and adult fish (Redden \& Daborn 1991, Flinkman et al. 1994). Lewis (1992), for example, found partly digested items on the surface of the gastrozoids of a cnidarian hydrocoral and Conway et al. (1993) reported egestion of intact copepod exoskeletons by fish larvae. Patches of relatively high carcass abundance over seamounts and banks were assumed to result from intensified zooplankton predation by nekton and micronekton residing above shallow topographic features (Haury et al. 1995).

Some investigators have considered the carcasses in samples an artifact (Wishner 1980, Wiebe et al. 1988). 
Mechanical damage caused by nets or during sample handling can produce empty or partly empty exoskeletons. Capture by nets or handling prior to preservation can cause predators to egest partly digested or release partly eaten copepods (e.g. from the feeding 'baskets' of euphausiids; Beyer 1992).

Zooplankton samples collected near the coral reef of Eilat, Red Sea, contained unusually high proportions of copepod carcasses. These carcasses did not appear to be an artifact of collection or handling. Here we describe the spatial distribution of the carcasses with respect to the coral reef and provide preliminary evidence for the role of predation in their production.

\section{METHODS}

The study was carried out near the northern end of the Gulf of Eilat, Israel, during summer (July to September) 1990 and 1991. Sea-surface temperatures varied from 26 to $27^{\circ} \mathrm{C}$ and salinity was nearly $40.5 \%$. Zooplankton were sampled at 2 sites: the middle section of the ca $1 \mathrm{~km}$ long fringing coral reef at the Nature Reserve of Eilat and a sandy coast about $6 \mathrm{~km}$ north of the reef. The latter site had a much more gradual slope (Fig. 1). The community at the reef site, described by Fishelson (1971) and Loya (1972), was rich in invertebrates and fish, particularly along the upper slope of the fore reef. The bottom at the sandy coast was sparsely covered by sea grass (Halophila stipulacea) and inhabited mostly by deposit feeders (Fishelson 1971). Benthic macrozooplanktivores, such as corals, sea anemones, hydrocorals, barnacles and crinoids, were probably orders of magnitude less abundant at the sandy shore than at the reef. Similarly, planktivorous fish were much more abundant at the reef. Although reef fishes are sometimes found away from the reef (Fishelson 1971, Hobson 1972, Hobson \& Chess 1973), they were rarely observed at the sandy site. Thus, the sandy coast site allowed a comparison of carcass distribution between a location with high abundances of macrobenthic and demersal zooplanktivores and one where such animals were rare.

Because the original goal of the sampling was to study zooplanktivory by diurnal coral-reef fish (A. Genin, G. Gal, D. Lindel \& S. Prado-Por unpubl.), all samples were collected during the day, mostly between 09:30 and 17:00 h local time. At each site, samples were taken along cross-shore transects. Each transect but one consisted of 4 tows, all at $4 \mathrm{~m}$ depth (Fig. 1). The shallowest tow was at the $5 \mathrm{~m}$ bottom contour (i.e. $1 \mathrm{~m}$ above bottom, or 'mab'), the second tow at $10 \mathrm{~m}$ ( $6 \mathrm{mab})$, the third $20 \mathrm{~m}$ (16 mab) and the fourth $40 \mathrm{~m}$ (36 mab). Tows at the sandy site were

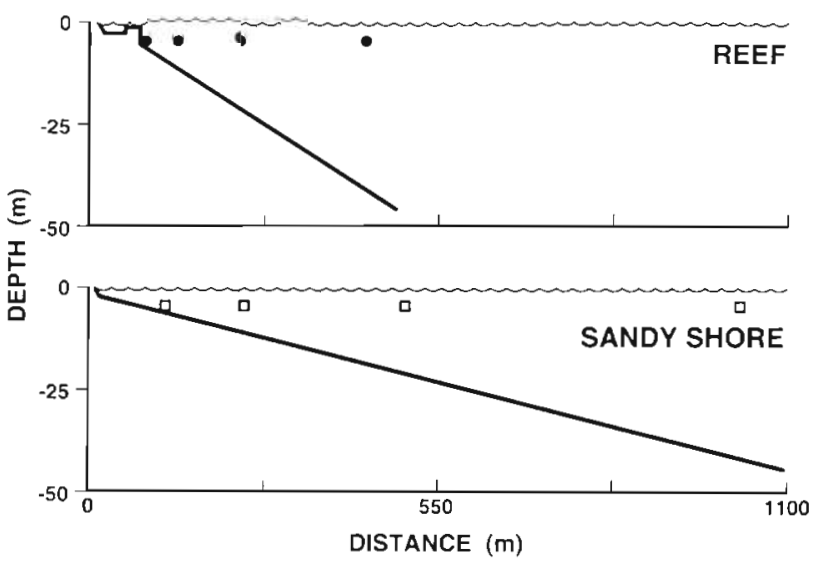

Fig. 1. Schematic drawing of bottom profiles (thick lines) and tow positions (circles and squares) across the coral reef and the sandy shore. A reef flat and shallow lagoon are found

shoreward of stations in the reef (uppermost left corner)

farther from shore than those at the coral reef due to the more gradual bottom slope of the sandy bottom (Fig. 1). Twelve transects (47 samples) were made at the reef and 5 transects (20 samples) were made at the sandy shore.

We used a $220 \mu \mathrm{m}$ mesh net $(2.0 \mathrm{~m}$ length, $56 \mathrm{~cm}$ diam.) and cod end. The net was towed by 2 SCUBA divers, one on each side, as in Hobson \& Chess (1976). Each tow, taken parallel to the shore above a constant bottom depth, lasted $5 \mathrm{~min}$ (length about $45 \mathrm{~m}$ or $11 \mathrm{~m}^{3}$ water filtered). A complete transect ( 4 tows) took about $2 \mathrm{~h}$. The net's mouth was tightly choked and folded over during lowering and retrieving. After the tow, the net was immediately transferred to a skiff where the animals were gently removed and preserved in glass jars $(4 \%$ buffered formalin in sea water), usually within 20 min of collection.

The samples were sorted with a dissecting microscope using dark-field illumination. Copepods were separated into calanoids and cyclopoids (including the poecilostomatoid families Oncaeidae, Corycaeidae and Sapphirinidae). The condition of each copepod was assigned to 1 of 3 categories: (1) 'husk', exoskeleton with little or no tissue $;$ (2) 'marginal', decayed internal structures; (3) 'live', no evidence of damage. Since decay of partly emptied carcasses can produce completely empty exoskeletons (Wheeler 1967, Harding 1973), no attempt was made to differentiate empty exoskeletons from molt exuviae. Following the procedures used by Haury et al. (1995), 'husk' and 'marginal' individuals were pooled into a group termed 'carcasses' (Wheeler 1967, Weikert 1977, Terazaki \& Wada 1988). Carcasses commonly had a fractured exoskeleton, but with setae and appendages intact.

Carcasses have not been reported in near-reef zooplankton (e.g. Tranter \& George 1972, Glynn 1973. 
Johannes \& Gerber 1974, Vaissiere \& Seguin 1984, Hamner et al. 1988, Williams et al. 1988), raising the possibility that our observations were due to net damage or sample handling. To address this question, we looked for carcasses in unpreserved, gently collected ('gentle') samples. These samples $(n=3)$ were collected (8-9 November 1994) by swimming slowly at the surface holding a small, $20 \mathrm{~cm}$ diameter, $220 \mu \mathrm{m}$ mesh hand net. The location was above the coral reef off the H. Steinitz Marine Biology Laboratory in Eilat, about $500 \mathrm{~m}$ south of our main reef site. This small (ca $100 \mathrm{~m}$ long), sloping reef is isolated from neighboring reefs by sand and rubble areas. After each tow, the net was taken immediately to the laboratory for microscopic classification of the copepods' conditions; examination started 8 to 10 min after each tow. Many copepods were still alive, facilitating the separation of live specimens from carcasses. Since these samples dif fered from those of the main study in time (year and season) and location (site and depth), no direct comparison of carcass proportions could be made. Nevertheless, we expected carcasses would be rare in our gentle samples if damage by net or preservation were major causes for their production.

Preliminary qualitative observations were carried out with several reef planktivores to see if they egest copepod carcasses. The predators were: (1) cnidarians that use tentacles with nematocysts - the sea anemone Boloceroides mcmurrichi $(\mathrm{n}=5$ ) and the hermatypic corals Stylophora pistillata $(\mathrm{n}=3)$, Favia sp. $(\mathrm{n}=1)$, and Fungia horrida ( $\mathrm{n}=2)$; (2) a passive-filtering echinoderm, the crinoid Tiopiometra carinata ( $\mathrm{n}=2)$; and (3) visual planktivorous fish - adult Dascyllus marginatus ( $\mathrm{n}=2$ ), adult Pseudanthias squamipinnis ( $\mathrm{n}=2$ ) and recently settled ( $\sim \mathrm{cm}$ standard length) coral-reef fish (family Sparidae; hereafter 'fish post-larvae') $(\mathrm{n}=19)$. Zooplanktivory by cnidaria and the fish is well documented. Crinoids also feed on zooplankton, although their main food, at least in numbers, is phytoplankton (Rutman \& Fishelson 1969, La Touche \& West 1980). The invertebrates were collected at night, since this is when most of them feed. The fish, diurnal visual predators, were collected during the day by SCUBA divers at 2 to $12 \mathrm{~m}$ depth. Adult fish were caught after being lightly anesthetized with quinaldine; the fish post-larvae were caught with a small hand net. After collection, animals were transferred to aquaria filled with filtered $(65 \mu \mathrm{m})$ sea water. All except the fish postlarvae were placed individually in separate aquaria. The post-larvae were divided into 2 groups ( $\mathrm{n}=10$ and 9), and placed in separate aquaria. After 15 to $36 \mathrm{~h}$, the aquaria water was filtered through $65 \mu \mathrm{m}$ mesh for microscopic examination for carcasses. A simultaneous control procedure used aquaria filled with filtered sea water but no predators.
Non-parametric statistics were used throughout because the original proportions and their arcsinetransformed values had low but near-critical values of $C$, the Cochran test statistic for homogeneity of variance (Winer 1971). The Kruskal-Wallis test was used to examine the effect of tow location (bottom contour) on the proportion of carcasses number of copepod carcasses divided by the total number of live and dead copepods in the sample). The Mann-Whitney $U$-test compared pairs of samples and the Wilcoxon signed-ranks test compared differences in carcass proportions between calanoid and cyclopoid copepods. Statistical analyses used SYSTAT version 5.03 (Wilkinson 1991).

\section{RESULTS}

Copepods were the dominant taxon in both the coral reef and sandy shore samples, comprising $70 \%$ $(\mathrm{SD}=14.9)$ of the total number of metazoan plankton retained by the $220 \mu \mathrm{m}$ mesh net.

The proportion of copepod carcasses decreased sharply seaward across the coral reef (Fig. 2); the effect of tow location (bottom depth) on carcass proportions was significant (Kruskal-Wallis, $p<0.003$ ). Carcass proportions at the sandy shore (Fig. 2) showed no effect of bottom depth (Kruskal-Wallis, $p>0.07$ ) and were significantly lower (Mann-Whitney, $p<0.03$ ) than those at the coral reef at all stations but the deepest $(40 \mathrm{~m} ; \mathrm{p}>0.5)$. The proportion of carcasses at $40 \mathrm{~m}$ depth was relatively low $(\sim 25 \%)$ at both sites, similar to those in the upper $20 \mathrm{~m}$ in the middle of the Gulf (A. Genin \& G. Gal unpubl. data).

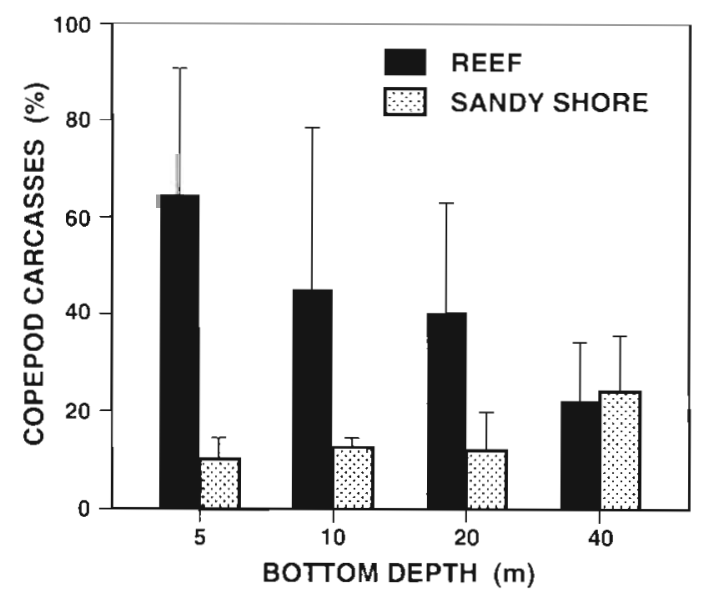

Fig. 2. Average proportions ( + SD) of copepod carcasses along the transects crossing the coral reef and the sandy shore. Coral reef proportions were significantly higher at 5,10 and $20 \mathrm{~m}$ depths (Mann-Whitney $U$-test, $\mathrm{p}<0.0001,<0.03$ and $<0.007$, respectively) but not at $40 \mathrm{~m}(\mathrm{p}>0.5)$ 

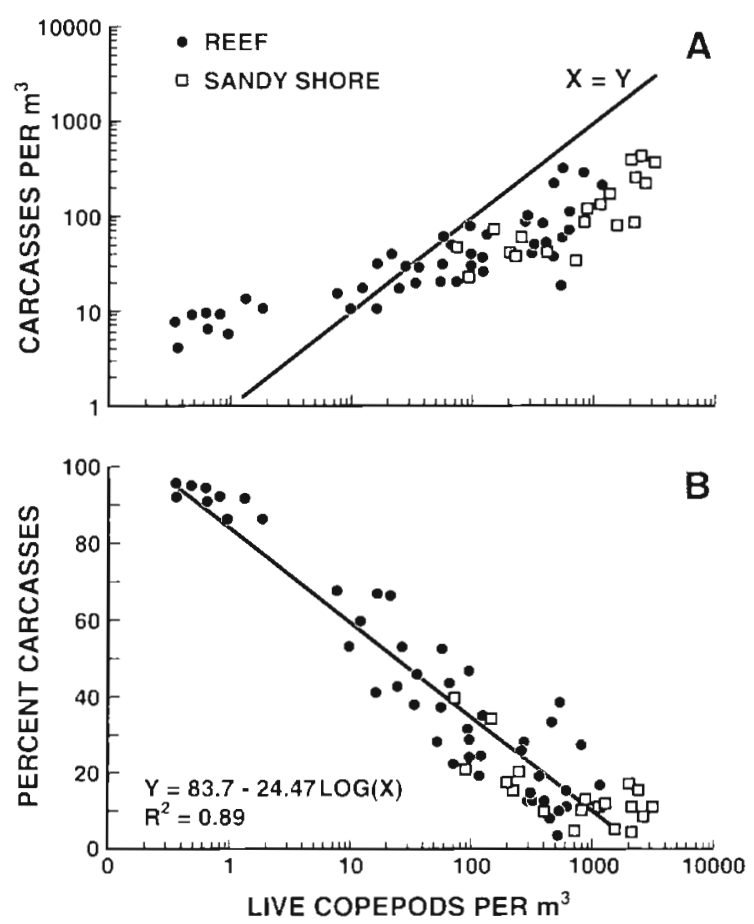

Fig. 3. Relationship between carcasses and live copepods at the coral reef ( ) and sandy shore ( $\square$ ). (A) Density of carcasses vs density of living copepods. Equal values are indicated by the straight line. Note that in samples with low total (live + dead) densities, data points are above the line, i.e. carcasses were more abundant than live individuals. (B) Proportions of carcasses vs density of live copepods. The linear regression model ( $p<0.0001$ ), used to draw the straight line, and the

corresponding $\mathrm{R}^{2}$ value are indicated at the lower left

The absolute abundance (no. $\mathrm{m}^{-3}$ ) of carcasses and live copepods (Fig. 3A) and total zooplankton (live and dead) co-varied (Spearman correlation coefficients of 0.87 and 0.88 , respectively; $n=67$ ). Proportions of carcasses increased exponentially with decreasing abundances of live copepods (Fig. 3B), following the regression model:

$$
P=83.7-24.47 \log x
$$

where $P$ is the proportion of copepod carcasses and $x$ the abundance (no. $\mathrm{m}^{-3}$ ) of live copepods $\left(\mathrm{R}^{2}=0.89\right.$ ). Carcass proportions higher than $80 \%$ occurred where the total zooplankton density was lower than 100 items $\mathrm{m}^{-3}$. Such low zooplankton densities were exclusively near the coral reef ( 5 and 10 m depths; Fig. 3B).

The proportions of carcasses were significantly higher (Wilcoxon, $\mathrm{p}<0.01$ ) for calanoid copepods than for cyclopoids (Table 1). The inter-taxon difference ( 7 to $8 \%$ ) was similar at both the reef and sandy sites.

The average ( $\pm \mathrm{SD}$ ) proportion of carcasses in the unpreserved, gently collected samples was $24.9 \%$ ( \pm 4.2 ) No predators that release partly digested copepods in
Table 1 Average (SD) proportions of carcasses of calanoid and cyclopoid copepods in the samples taken across the reef and sandy shore. Significance levels ( $p$ ) are for inter-taxon comparisons using the Wilcoxon signed-ranks test

\begin{tabular}{|lcccc}
\hline Site & Calanoids & Cyclopoids & $\mathrm{n}$ & $\mathrm{p}$ \\
\hline Reef & $45(29)$ & $37(30)$ & 47 & $<0.001$ \\
Sandy shore & $17(10)$ & $10(7)$ & 20 & $<0.01$
\end{tabular}

the net (e.g. euphausiids or gelatinous zooplankton; Beyer 1992) were found in these samples.

Carcasses similar to those found in our field samples were egested by the crinoids ( 2 to 3 carcasses per individual) and fish post-larvae ( $>15$ carcasses per group) (Fig. 4). Carcasses egested by crinoids were in feces, whereas the fish post-larvae egested individual carcasses. Feces of adult fish were tightly compacted within a thin, tough, peritrophic membrane and contained small, deformed exoskeleton fragments. Unlike the slow-sinking and easily resuspended carcasses egested by the post-larvae, the feces of the adult fish
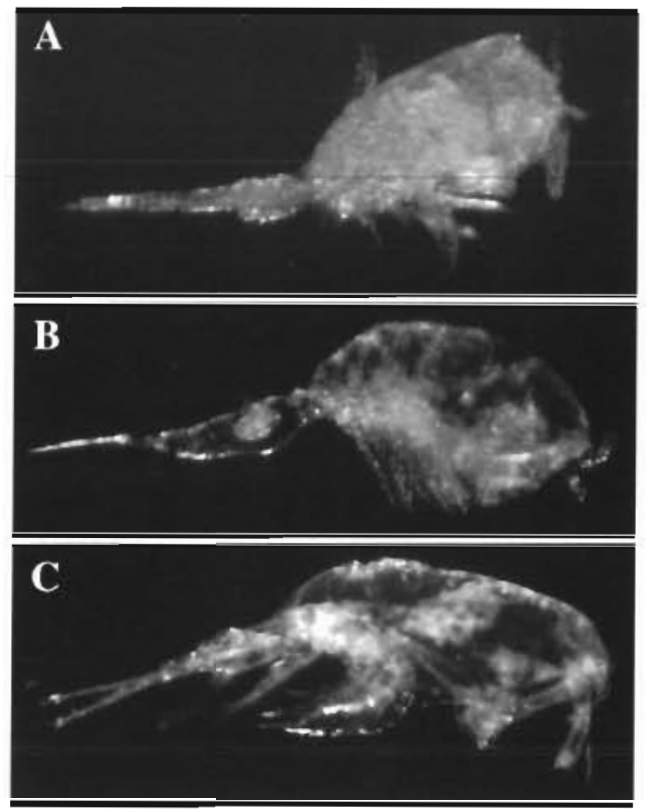

Fig. 4. Photographs of a 'live' copepod and 2 carcasses. (A) 'Normai' copepod (Corycaeus sp.), caught alive in a nearcoral-reef plankton low. (B) Carcass (Oncaea sp.) egested by a recently settled juvenile coral-reef fish (family Sparidae). (C) Carcass (Corycaeus sp.) egested by the coral-reef crinoid Triopiometra carinata. The specimens were preserved in buffered formalin for a few weeks before being photographed. The transparent appearance and the intact appendages and setae of the carcasses are typical of. all carcasses collected during our study and are similar to those figured in Wheeler (1967), Beyer (1992) and Haury et al. (1995). Total lengths: / B) $0.8 \mathrm{~mm}$; (C) $1.2 \mathrm{~mm}$ 
sank rapidly to the bottom of the aquaria. No complete carcasses or broken exoskeletons were found in the aquaria containing corals and sea anemones or in the control (no predator) aquaria.

\section{DISCUSSION}

Several investigators have attributed the empty or partly empty exoskeletons in zooplankton samples to damage by net or sample handling (Wishner 1980 . Wiebe et al. 1988). Others assert that some specimens were captured dead (Farran 1926, Wheeler 1967, Weikert 1977, Sameoto 1986, Terazaki \& Wada 1988, Geynrikh 1992). Two lines of evidence support natural processes, rather than post-capture artifacts, as the cause of the carcasses we observed. First, about $25 \%$ the copepods collected in the gentle tows were carcasses; these were similar in appearance to those collected during our main study. Carcasses would have been rare in the gentle samples if post-capture damage was important in their production. A second, more compelling, argument is the significant spatial pattern found in proportion of carcasses (Fig. 2). Since identical sampling and handling protocols were used for all the cross-shore work, neither a cross-shore gradient nor inter-site differences would have been expected if carcasses were a sampling artifact.

Other possible causes for carcasses include accumulation of exoskeletons at density fronts (Terazaki \& Wada 1988) and starvation (Weikert 1977). Both causes are unlikely in our case for the following reasons. First, no oceanographic front occurred across the rather small spatial span of our transects (B. Lazar \& J. Erez unpubl. data). Second, the residence time of water along the reef was rather short, typically $<8 \mathrm{~h}$ along the $5 \mathrm{~m}$ depth contour (A. Genin \& G. Gal unpubl. drogue drifter data), so that an entrapment of fooddepleted waters near the reef causing mass copepod starvation was unlikely.

Some of the carcasses in our samples may have resulted from resuspension of carcasses that had settled to the bottom at an earlier time. That resuspension is not a major source of carcasses is suggested by the difference between carcass proportions over the reef and sandy shore (same altitudes above the bottom) and the lack of a cross-shore gradient at the latter site. The increase in carcass proportions was associated with the proximity of the reef itself, rather than the co-occurring change in bottom depth.

Carcasses most likely resulted from predation on zooplankton by reef inhabitants. Zooplanktivory in waters flowing over coral reefs is intense (Glynn 1973, Johannes \& Gerber 1974, Hamner et al. 1988, A. Genin, G. Gal \& D. Lindel unpubl. data) and the 2 taxa of predators that egested carcasses in our aquaria are very common in Indo-Pacific reefs (e.g. Fishelson 1974, Sale 1980, Williams et al. 1988). Fish post-larvae were abundant; our shallower tows on the reef transects, where carcasses comprised 60 to $95 \%$ of all copepods, passed through the foraging ranges of numerous planktivorous fish of all sizes. On the other hand, crinoids had become rare at the Nature Reserve of Eilat prior to our study for unknown reasons (Erez 1992).

It is surprising that no carcasses were produced by the cnidaria included in our laboratory observations. Sebens \& Koehl (1984) and Sebens (pers. comm.) observed the egestion of mucus-wrapped boluses from the mouths of some cnidaria, but no intact carcasses were observed in the boluses. The coelenterons of the sea anemone and soft coral studied by Sebens \& Koehl (1984) contained small, partly digested fragments of crustaceans a few hours after feeding. It is therefore possible that copepods eaten by the cnidaria were broken into fragments too small to be retained by the $65 \mu \mathrm{m}$ mesh we used to filter the water after aquarium incubations. If severe fragmentation is true for most cnidaria, then corals and sea anemones, although abundant in the reef, are not major producers of the carcasses observed in our cross-shore transects.

Incomplete digestion of copepods is apparently a general phenomenon in fish larvae (Rosenthal \& Hempel 1970, Chitty 1981, Checkley 1982, Conway et al. 1993). Conway et al. (1993) noted that feces of larval Scophthalmus maximus (a turbot) contained intact copepod exoskeletons, some empty ('husks', according to our definition) and some containing undigested material ('marginal'). The fragmentation and deformation of exoskeletons in the feces of the adult fish indicate that they are not a major contributor of copepod carcasses.

It is not clear why proportions of calanoid carcasses were higher than those of cyclopoids. It might reflect inter-taxon differences in digestibility (Conway et al. 1993). Selective predation could also be a factor. Johnson \& Sebens (1993), for example, found that the coral Meandrina meandrites selected for calanoids and against cyclopoids. Differential predation could be related to differences in the swimming characteristics of the 2 taxa (Gauld 1966) or their ability to evade predators. Size, too, may play a role. The calanoid copepods at the reef site were, on the average, larger than the cyclopoids (a difference of about $8 \%$, or $50 \mu \mathrm{m}$; G. Gal unpubl. data). Calanoids might therefore be a preferred prey for visual predators such as fish post-larvae.

The exponential relationships between the proportion of carcasses and the abundance of live copepods (Fig. 3B) are intriguing. The highest proportions of carcasses were found in samples taken at sites with extremely low zooplankton abundance; these sites 
were all adjacent to the predator-rich coral reef. Such exponential relationships could be associated with predation under the following assumptions: (1) all water parcels moving from open areas toward the reef initially have similar copepod densities, (2) the decrease in copepod density is caused primarily by predation, and (3) a fixed proportion of those copepods preyed upon become carcasses. A test of this model would require detailed information (not now available) on predation rates, carcass-production ratios (number of carcasses produced relative to total copepods consumed by a predator), sinking rates of carcasses and the history of water parcels.

Reef predators that selected living individuals and rejected carcasses, but that did not produce carcasses themselves, would also cause a reefward increase in the proportion of carcasses. Overall, the observed cross-reef pattern probably results from a complex interaction of carcass production, selective predation on living individuals, and sinking and resuspension of carcasses.

Our sampling program had several limitations: the cross-shore transects were taken only during summer, they were all diurnal and, in the case of the shallowest tows, were very close to the bottom (1 mab). Both the current regime (A. Genin, A. Wolf-Vecht \& N. Paldor unpubl.) and abundance of zooplanktivores, specifically fish larvae (D. Shapiro \& A. Kushnir pers. comm.). exhibit strong seasonality in the Gulf of Eilat. A more detailed study is required to examine the temporal and vertical variations in copepod carcasses near the reef. The lower proportions of carcasses found in our gentle samples, taken at a different depth and season than our main study, suggest that such variations might be substantial. The situation where carcasses form a high proportion of the zooplankton near the reef is expected to dramatically change at night, when emerging demersal zooplankters swamp the waters over the reef (e.g. Alldredge \& King 1977, Porter \& Porter 1977).

Carcasses are obviously less nutritious than living copepods (Wheeler 1967, Terazaki \& Wada 1988, Conway et al. 1993). Since copepods are often a dominant component of zooplankton communities (Weikert 1977, Wishner 1980, this study), and since the external appearance of carcasses is almost identical to that of living individuals, the ability of predators to distinguish between these 2 forms of prey would be critical. At our reef site, for example, there were times when over $90 \%$ of the potential prey for zooplanktivores were the less nutritious carcasses. Whether coralreef planktivores can distinguish between live and dead prey is unknown. Investigations of zooplankton dynamics at sites where predation is intense should consider the presence of copepod carcasses.
Acknowledgements. We thank P. Sulkis, D. Lindell and I. Ayalon for sorting the samples and for assistance with the field work along with R. Grossman, R. Goldberg, B. Moravchik and I. Lherer. We thank D. Checkley, A. Shanks, J. Purcell and $\mathrm{K}$. Sebens for suggesting potential producers of carcasses. Comments by D. Lindell, B. Farstey, Q. Bone and 2 anonymous reviewers have improved the manuscript. Supported by grants from the United States-Israel Binational Science Foundation (BSF \#88-351) and the Wolfson Research Awards administered by the Israel Academy of Sciences and Humanities

\section{LITERATURE CITED}

Alldredge AL, King JM (1977) Distribution, abundance, and substrate preferences of demersal reef zooplankton at Lizard Island lagoon, Great Barrier Reef. Mar Biol 41: $317-333$

Beyer F (1992) Meganyctiphanes norvegica (M. Sars) (Euphausiacea) a voracious predator on Calanus, other copepods, and ctenophores, in Oslofjorden, southern Norway. Sarsia 77:189-206

Checkley DM (1982) Selective feeding by Atlantic herring (Clupea harengus) larvae on zooplankton in natural assemblages. Mar Ecol Prog Ser 9:245-253

Chitty N (1981) Behavioral observations of feeding larvae of bay anchovy, Anchoa mitchilli, and bigeye anchovy, Anchoa lamproteania. Rapp P-v Réun Cons int Explor Mer 178:320-321

Conway DVP, Tranter PRG, Coombs SH (1993) Digestion of natural food by the larval and post-larval turbot Scophthalmus maximus. Mar Ecol Prog Ser 100:221-231

Erez D (1992) "The effects of water flow on suspension feeding crinoids (Echinodermata: Crinoidae). MSc thesis, The Hebrew University of Jerusalem (in Hebrew)

Farran GP (1926) Biscayan plankton collected during a cruise of H.M.S. 'Research', 1900. Part XIV. The Copepoda. $J$ Linn Soc (Zool) 36:219-310

Fishelson L (1971) Ecology and distribution of the benthic fauna in the shallow waters of the Red Sea. Mar Biol 10: $113-133$

Fishelson L (1974) Ecology of the northern Red Sea crinoids and their epi- and endozoic fauna. Mar Biol 26:183-192

Flinkman J, Vuorinen I, Christiansen M (1994) Calanoid copepod eggs survive passage through fish digestive tracts. ICES J mar Sci 51:127-129

Gauld DT (1966) The swimming and feeding of planktonic copepods. In: Barnes $\mathrm{H}$ (ed) Some contemporary studies in marine science. George Allen and Unwin, London, p $313-334$

Geynrikh AK (1992) Copepods in the bottom layer of Walters Seamount (southwestern Indian Ocean). Oceanology 32: $84-88$

Glynn PW (1973) Ecology of a Caribbean coral reef. The Porites reef-flat biotop: Part Ir. Plankton community with evidence for depletion. Mar Biol 22:1-21

Hamner WH, Jones MS, Carleton JH, Hauri IR, Williams $\mathrm{DMcB}$ (1988) Zooplankton, planktivorous fish, and water currents on a windward reef face: Great Barrier Reef, Australia. Bull mar Sci 42:459-479

Harding GCH (1973) Decomposition of marine copepods. Limnol Oceanogr 18:670-673

Haury L, Fey C, Gal G, Hobday A, Genin A (1995). Copepod carcasses in the ocean. I. Over seamounts. Mar Ecol Prog Ser 123:57-63

Hobson ES (1972) Activity of Hawaiian reef fishes during the 
evening and morning transitions between daylight and darkness. Fish Bull US 70:715-740

Hobson ES, Chess JR (1973) Feeding oriented movements of the atherinid fish Pranesus pinquis at Majuro Atoll, Marshall Islands. Fish Bull US 71:777-786

Hobson ES, Chess JR (1976) Trophic interactions among fishes and zooplankters near shore at Santa Catalina Island, California. Fish Bull 74:567-598

Johannes RE, Gerber R (1974) Import and export of net plankton by an Eniwetok coral reef community. In: Great Barrier Reef Committee, Proc 2nd Int Coral Reef Symp. Brisbane, p 97-104

Johnson AS, Sebens KP (1993) Consequences of a flattened morphology: effects of flow on feeding rates of the scleractinian coral Meandrina meandrites. Mar Ecol Prog Ser 99: 99-114

La Touche RW, West AB (1980) Observations on the food of Antedon bifida (Echinodermata: Crinoidea). Mar Bial 60: $39-46$

Lewis JB (1992) Heterotrophy in corals: zooplankton predation by the hydrocoral Millepora complanata. Mar Ecol Prog Ser 90:251-256

Loya Y (1972) Community structure and species diversity of hermatypic corals in Eilat, Red Sea. Mar Biol 13:100-123

Ohman MD (1984) Omnivory by Euphausia pacifica: the role of copepod prey. Mar Ecol Prog Ser 19:125-131

Ponomareva LA (1954) Copepods in the diet of euphausiids of the Sea of Japan. Dokl Akad Nauk SSSR 98:153-154

Porter JW, Porter KG (1977) Quantitative sampling of demersal plankton migrating from different coral reef substrates. Limnol Oceanogr 22:553-556

Redden AM, Daborn GR (1991) Viability of subitaneous copepod eggs following fish predation on egg-carrying calanoids. Mar Ecol Prog Ser 77:307-310

Roe HSJ (1988) Midwater biomass profiles over the Madeira abyssal plain and the contribution of copepods. Hydrobiologia 167/168:169-181

Rosenthal H. Hempel G (1970) Experimental studies in feeding and food requirements of herring larvae (Clupea harengus L.). In: Steele JH (ed) Marine food chains. University of California Press, Berkeley, p 344-364

Rutman J, Fishelson L (1969) Food composition and feeding behavior of shallow-water crinoids at Eilat (Red Sea). Mar

This article was presented by J. E. Purcell (Senior Editorial Advisor), Cambridge, Maryland, USA
Biol 3:46-57

Sale PF (1980) The ecology of fishes on coral reefs. Oceanogr mar Biol A Rev 18:367-421

Sameoto DD (1986) Influence of the biological and physical environment on the vertical distribution of mesozooplankton and micronekton in the eastern tropical Pacific. Mar Biol 93:263-279

Sebens KP, Koehl MAR (1984) Predation on zooplankton by the benthic anthozoans Alcyonium siderium (Alcyonacea) and Metridium senile (Actiniaria) in the New England subtidal. Mar Biol 81:255-271

Terazaki M, Wada M (1988) Occurrence of large numbers of carcasses of the large, grazing copepod Calanus cristatus from the Japan Sea. Mar Biol 97:177-183

Tranter DJ, George J (1972) Zooplankton abundance at Kavaratti and Kalpeni Atolls in the Laccadives. In: Mukundan C, Gopindaha Pillai CS (eds) Proc 1st Int Symp Corals and Coral Reefs, 1969. Mar Biol Assoc India, Cochin, p 239-256

Vaissiere R, Seguin G (1984) Initial observations on the zooplankton microdistribution on the fringing coral reef at Aqaba (Jordan). Mar Biol 83:1-11

Weikert $H$ (1977) Copepod carcasses in the upwelling region south of Cap Blanc, N.W. Africa. Mar Biol 42:351-355

Wheeler EH (1967) Copepod detritus in the deep sea. Limnol Oceanogr 12:697-701

Wiebe $\mathrm{PH}$, Copley $\mathrm{N}$, Van Dover C, Tamse A, Manrique F (1988) Deep-water zooplankton of the Guaymas Basin hydrothermal vent field. Deep Sea Res 35:985-1013

Wilkinson L (1991) SYSTAT: statistics, DOS version 5.03. SYSTAT, Inc, Evanston, IL.

Williams DMcB, Dixon P, English S (1988) Cross-shelf distribution of copepods and fish larvae across the central Great Barrier Reef. Mar Biol 99:577-589

Winer BJ (1971) Statistical principles in experimental design. McGraw-Hill, Tokyo

Wishner KF (1980) Aspects of the community ecology of deepsea, benthopelagic plankton, with special attention to gymnopleid copepods. Mar Biol 60:179-187

Wishner $K$, Durbin E, Durbin A, Macaulay $M$, Winn $H$, Kenney R (1988) Copepod patches and right whales in the Great South Channel off New England. Bull mar Sci $43: 825-844$

Manuscript first received: July 14, 1994

Revised version accepted: January 31, 1995 